\title{
PENGARUH PEMBELAJARAN QUANTUM BERBANTUAN PERMAINAN DALAM PEMBELAJARAN TERHADAP KEAKTIFAN DAN HASIL BELAJAR KOGNITIF IPA SISWA KELAS V
}

\author{
Ni Nyoman Nitha Samadhi 1,*, Putu Nanci Riastini2 \\ 1 Jurusan Pendidikan Guru Sekolah Dasar, FIP, Universitas Pendidikan Ganesha \\ 2 Jurusan Pendidikan Guru Sekolah Dasar, FIP, Universitas Pendidikan Ganesha
}

\begin{abstract}
This research aims is to determine the differences of activity and learning outcomes of science between groups of students who were taught by learning Quantum assisted games and groups of students who were taught not with learning Quantum assisted game to elementary school students in V grade at Gugus II Santalia, Kubutambahan district, in academic year 2016/2017. This type of research is quasi experiment, with non equivalent design post test only control group design. The population in this study is the entire class V of elementary school in gugus II Santalia. The research sample in class $V$ elementary school number 1 Kubutambahan as experimental group and class $\mathrm{V}$ elementary school number 7 Kubutambahan as control group obtained by random sampling technique by way of class lottery. Analytical methods that used in this study consist of descriptive analysis and inferential analysis using the t-test (polled variance). The results showed that there was a difference of activity and learning outcomes between the experimental group and the control group. The findings are that students become more active, enthusiastic, and happy during the learning process. In addition the steps of learning Quantum help students more easily understand the material. Thus the learning of Quantum-assisted games has an effect on the activity and learning outcomes of science students of grade V in Gugus II Santalia Kubutambahan distric of academic year 2016/2017.
\end{abstract}

\author{
Keywords: \\ Quantum, Game activity, \\ Learning outcomes
}

\section{Introduction}

Pendidikan memegang peranan yang sangat penting dalam upaya meningkatkan kualitas sumber daya manusia (SDM). Terkait dengan pentingnya pendidikan untuk meningkatkan kualitas SDM, suasana belajar di sekolah perlu direncanakan sedemikian rupa menggunakan pembelajaran yang tepat. Tepat yang dimaksudkan adalah sesuai dengan mata pelajaran dan materi yang akan dibelajarkan, sehingga siswa memperoleh kesempatan untuk berinteraksi satu sama lain. Pembelajaran yang demikian membuat siswa akan terlibat secara aktif, baik mental, fisik, maupun sosialnya, sehingga pembelajaran akan bermakna bagi siswa (Susanto, 2013). Pembelajaran yang demikian harus terjadi pada semua mata pelajaran yang diterapkan di sekolah, termasuk pada mata pelajaran IPA.

IPA merupakan mata pelajaran yang wajib diberikan di Sekolah Dasar. Mata pelajaran ini memegang peranan penting dalam kehidupan sehari-hari, sebab IPA melatih siswa berfikir logis, rasional, kritis, kreatif, dan berpikir secara ilmiah (Samatowa, 2016). IPA juga memiliki peranan yang sangat penting dalam pembentukan kepribadian dan perkembangan intelektual anak. Oleh karena pentingnya pendidikan IPA di SD, maka sangat diperlukan pembelajaran yang sesuai dengan karakteristiknya, sehingga siswa belajar IPA secara bermakna. Belajar bermakna yang dimaksud dalam pembelajaran IPA adalah siswa mampu memperoleh pemahaman berdasarkan apa yang dilihat, didengar, dirasakan, dan dialami sendiri oleh siswa (Suastra, 2009). Terciptanya pembelajaran bermakna dipengaruhi oleh tingkat

\footnotetext{
* Corresponding author.

E-mail Addresses nithasamadhi03@gmail.com (Ni Nyoman Nitha Samadhi), chem_currie@yahoo.com (Putu Nanci Riastini),
} 
keaktifan siswa dalam proses pembelajaran. Keaktifan siswa dalam belajar akan memberikan kesempatan yang lebih luas untuk memperoleh dan memahami pengetahuan baru (Ambarjaya, 2012). Keaktifan yang ditunjukkan oleh siswa dalam pembelajaran akan mempengaruhi seberapa besar pemahaman dan hasil belajar yang diperoleh siswa. Tingkat keaktifan siswa yang tinggi dalam pembelajaran IPA akan menyebabkan pemahaman siswa menjadi lebih luas dan hasil belajar siswa juga akan meningkat.

Namun kenyataannya, keaktifan siswa belum sesuai harapan, termasuk di sekolah dasar. Berdasarkan hasil observasi yang dilakukan pada tanggal 31 Desember 2016 hingga tanggal 4 Januari 2017 di seluruh kelas V SD di Gugus II Santalia, siswa terlihat kurang aktif dalam mengikuti pembelajaran. Hal ini terbukti pada saat guru menerangkan, sebanyak 35\% siswa yang mengobrol dengan teman sebangkunya. Ada sebanyak 45\% yang bermain dengan teman di dekatnya. Selain hal tersebut, pada saat guru memberikan kesempatan kepada siswa untuk bertanya mengenai materi yang dibahas, tidak ada siswa yang bertanya. Ketika diberikan kesempatan untuk menjawab soal, hanya ada 2 hingga 4 siswa yang angkat tangan untuk menjawab. Berdasarkan hasil observasi, data keaktifan belajar siswa terlihat pada Tabel 1.

Tabel 1. Rata-rata Nilai Keaktifan Belajar Siswa Kelas V SD di Gugus II Santalia Semester I Tahun Pelajaran $2015 / 2016$

\begin{tabular}{ccc}
\hline No. & Nama & Rata-rata nilai siswa \\
\hline 1 & Kelas V SDN 1 Kubutambahan & 38,56 \\
2 & Kelas V SDN 2 Kubutambahan & 35,88 \\
3 & Kelas V SDN 3 Kubutambahan & 35,03 \\
4 & Kelas V SDN 4 Kubutambahan & 40,07 \\
5 & Kelas V SDN 5 Kubutambahan & 36,63 \\
6 & Kelas V SDN 6 Kubutambahan & 38,74 \\
7 & Kelas V SDN 7 Kubutambahan & 39,4 \\
\hline
\end{tabular}

Berdasarkan Tabel 1, rata-rata keaktifan belajar siswa berada pada kategori rendah mengacu pada standar PAP yang ditetapkan. Kenyataan keaktifan siswa yang demikian berdampak pula terhadap rendahnya hasil belajar siswa, terutama hasil belajar ranah kognitif. Berdasarkan hasil pencatatan dokumen yang dilakukan pada tanggal 31 Desember 2016 hingga tanggal 4 Januari 2017, diperoleh data seperti pada Tabel 2 .

Tabel 2. Rata-rata Nilai Mata Pelajaran IPA Siswa Kelas V SD di Gugus II Santalia Semester I Tahun Pelajaran 2015/2016

\begin{tabular}{ccc}
\hline No. & Nama & Rata-rata nilai siswa \\
\hline 1 & Kelas V SDN 1 Kubutambahan & 67,06 \\
2 & Kelas V SDN 2 Kubutambahan & 62,69 \\
3 & Kelas V SDN 3 Kubutambahan & 64,77 \\
4 & Kelas V SDN 4 Kubutambahan & 70,57 \\
5 & Kelas V SDN 5 Kubutambahan & 63,40 \\
6 & Kelas V SDN 6 Kubutambahan & 65,97 \\
7 & Kelas V SDN 7 Kubutambahan & 64,87 \\
\hline
\end{tabular}

Berdasarkan Tabel 2, terlihat bahwa rata-rata nilai siswa kelas V berada pada kategori cukup mengacu pada standar PAP yang ditetapkan. Pembelajaran yang demikian disebabkan karena beberapa hal. Pertama, siswa merasa malu dan takut salah dalam berpendapat, sehingga mereka memilih diam. Artinya, pembelajaran belum membudayakan mereka untuk aktif berbicara. Kedua, guru hanya mengajar dengan ceramah dan tanya jawab. Akibatnya, pembelajaran menjadi kurang menarik, siswa cenderung pasif, hanya mencatat, dan mendengarkan sesuai perintah guru tanpa berupaya untuk mengalami sendiri agar memahami konsep-konsep yang dipelajari. Dengan demikian, pembelajaran menjadi kurang menyenangkan dan hanya berpusat pada guru. Ketiga, selama proses pembelajaran guru hanya menggunakan media sebanyak 1 hingga 2 kali pertemuan dalam satu semester. Akibatnya, siswa sulit memahami materi yang diberikan karena siswa tidak melihat atau mengalami langsung pembelajaran yang diberikan.

Berdasarkan uraian masalah rendahnya keaktifan dan hasil belajar siswa pada mata pelajaran IPA beserta penyebabnya tersebut, perlu dicarikan suatu solusi. Salah satu solusi yang digunakan adalah pembelajaran yang lebih inovatif dan menciptakan suasana belajar yang aktif. Sejalan dengan hal tersebut, pembelajaran inovatif diharapkan dapat menarik minat siswa untuk mempelajari IPA dan dapat 
mendorong siswa untuk lebih berperan aktif dalam belajar, sehingga berdampak pada hasil belajar yang dicapai oleh siswa.

Salah satu pembelajaran yang sesuai untuk menyelesaikan masalah tersebut adalah pembelajaran Quantum. Pembelajaran Quantum memberikan kesempatan kepada siswa untuk mengaitkan segala interaksi dan perbedaan dalam memaksimalkan momen belajar. Pembelajaran ini menekankan pada siswa untuk menumbuhkan minat belajar, mengalami langsung pembelajaran yang diberikan, menamai, mengulangi pembelajaran, dan merayakan hasil pembelajaran. Deporter (2010) mengartikan pembelajaran Quantum menciptakan pembelajaran yang meriah dengan segala nuansanya. Kemeriahan yang dimaksud akan tercipta dengan keterlibatan aktif seluruh siswa dalam pembelajaran. Menurut Usman (dalam Suwatra, dkk, 2015), keterlibatan aktif seluruh siswa akan menjadikan pembelajaran efektif dan siswa dapat mencapai hasil belajar yang diinginkan.

Kemeriahan ini bisa dimaksimalkan dengan berbantuan permainan. Permainan akan membuat siswa lebih aktif dalam mengikuti pembelajaran dari awal hingga akhir pembelajaran. Permainan yang dapat diterapkan dalam pembelajaran Quantum meliputi permainan puzzle, bingo, ular tangga, dan tekateki silang. Permainan tersebut dilaksanakan pada tahap "Alami dan Namai" dalam rancangan pembelajaran Quantum. Permainan tersebut melibatkan keaktifan seluruh siswa. Terlibatnya siswa dalam permainan membantu siswa memahami materi menjadi lebih mudah. Hal ini dikarenakan permainan memberikan kesempatan lebih banyak kepada siswa untuk bereksplorasi, sehingga konsep-konsep yang dipelajari dapat dipahami dengan mudah oleh siswa (Sudono, 2000). Hal ini dapat membantu siswa untuk lebih mudah mencapai hasil belajar yang diinginkan.

Berdasarkan hal tersebut, pembelajaran Quantum dengan permainan memiliki pengaruh terhadap keaktifan dan hasil belajar siswa. Namun besarnya pengaruh pembelajaran Quantum dengan permainan belum dapat diketahui. Berdasarkan pemikiran tersebut, maka dilakukan penelitian yang berjudul "Pengaruh Pembelajaran Quantum Berbantuan Permainan dalam Pembelajaran Terhadap Keaktifan dan Hasil Belajar Kognitif IPA Siswa Kelas V di Gugus II Santalia Kecamatan Kubutambahan Tahun Pelajaran 2016/2017".

\section{Metode}

Penelitian ini termasuk penelitian eksperimen semu (Quasi Eksperiment) karena tidak semua variabel yang relevan dapat dikontrol atau dimanipulasi, kecuali beberapa variabel yang diteliti. Rancangan penelitian yang digunakan adalah Non-Equivalent Posttest Only Control Group Design. Populasi dalam penelitian ini adalah seluruh kelas V SD di Gugus II Santalia Kecamatan Kubutambahan. Distribusi anggota populasi dapat dilihat pada Tabel 3.

Tabel 3. Distribusi Populasi Penelitian

\begin{tabular}{clc}
\hline No. & \multicolumn{1}{c}{ Nama } & Jumlah Siswa \\
\hline 1 & Kelas V SDN 1 Kubutambahan & 31 \\
2 & Kelas V SDN 2 Kubutambahan & 26 \\
3 & Kelas V SDN 3 Kubutambahan & 31 \\
4 & Kelas V SDN 4 Kubutambahan & 28 \\
5 & Kelas V SDN 5 Kubutambahan & 35 \\
6 & Kelas V SDN 6 Kubutambahan & 39 \\
7 & Kelas V SDN 7 Kubutambahan & 30 \\
& Jumlah Populasi & 220 \\
\hline
\end{tabular}

Berdasarkan Tabel 3. jumlah sekolah dalam gugus ini sebanyak 7 sekolah dengan anggota populasi sebanyak 220 siswa. Sampel pada penelitian ini dipilih dengan teknik Random Sampling, melalui cara undian kelas. Sebelum pengundian, dilakukan uji kesetaraan. Analisis yang digunakan dalam uji kesetaraan yaitu analisis varians satu jalur (ANAVA A). Berdasarkan analisis uji kesetaraan keaktifan belajar, pada taraf signifikansi 5\%, diperoleh nilai $F_{\text {hitung }}$ sebesar 0,41 dan nilai $\mathrm{F}_{\text {tabel }}$ sebesar 2,18. Artinya, seluruh kelas V di Gugus II Santalia memiliki keaktifan belajar yang setara. Berikutnya, berdasarkan

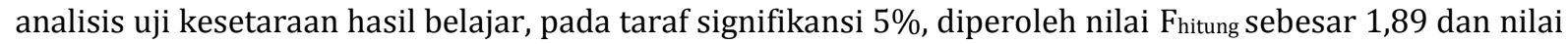
$F_{\text {tabel }}$ sebesar 2,18. Artinya, seluruh kelas V di Gugus II Santalia memiliki kemampuan akademik yang setara, sehingga pemilihan sampel dari populasi dapat dilakukan dengan teknik random. Berdasarkan hasil uji kesetaraan, dipilih 2 kelas sebagai sampel penelitian dari 7 kelas dalam populasi. Berdasarkan pengundian yang dilakukan, kelas yang menjadi sampel dalam penelitian dapat dilihat pada Tabel 4. 
Tabel 4. Sampel Penelitian

\begin{tabular}{|c|c|c|c|c|}
\hline No. & Sampel & Kelompok & Pendekatan/Model Pembelajaran & $\begin{array}{l}\text { Jumlah } \\
\text { Siswa }\end{array}$ \\
\hline 1 & $\begin{array}{l}\text { Kelas V SDN } 1 \\
\text { Kubutambahan }\end{array}$ & Eksperimen & Pembelajaran quantum berbantuan permainan & 31 \\
\hline 2 & $\begin{array}{l}\text { Kelas V SDN } 7 \\
\text { Kubutambahan }\end{array}$ & Kontrol & $\begin{array}{l}\text { Pembelajaran bukan dengan pembelajaran quantum } \\
\text { berbantuan permainan }\end{array}$ & 30 \\
\hline \multicolumn{4}{|c|}{ Total Sampel } & 61 \\
\hline
\end{tabular}

Berdasarkan Tabel 4, sampel dalam penelitian ini adalah kelompok siswa kelas V di SDN 1 Kubutambahan yang berjumlah 31 orang sebagai kelompok eksperimen dan kelas V di SDN 7 Kubutambahan yang berjumlah 30 orang sebagai kelompok kontrol.

Metode yang digunakan untuk mengumpulkan data keaktifan belajar IPA yaitu, menggunakan lembar observasi. Metode tes digunakan untuk pengumpulan data hasil belajar kognitif dalam pelajaran IPA. Pada kelompok eksperimen, pengukuran keaktifan belajar dilakukan menggunakan lembar observasi keaktifan siswa pada rentangan skor minimal 0 dan skor maksimal 24, sedangkan pada kelompok kontrol berada pada rentangan skor minimal 0 dan skor maksimal 16. Instrumen yang digunakan untuk memperoleh data hasil belajar IPA pada ranah kognitif adalah tes hasil belajar IPA. Tes hasil belajar dibuat dalam bentuk pilihan ganda sebanyak 25 butir soal. Tes hasil belajar dibuat dalam bentuk pilihan ganda yang diberikan pada saat post-test. Jawaban yang benar mendapat skor 1 (satu) dan jawaban yang salah mendapat skor 0 (nol).

Setelah instrumen tersusun, agar instrumen itu memenuhi syarat instrument yang baik, maka dilakukan pengujian instrument. Pengujian instrumen dilakukan mulai dari uji validitas isi oleh para ahli di bidang keaktifan belajar dan di bidang IPA. Selanjutnya, instrumen hasil belajar IPA yang telah mendapat pertimbangan pakar diujicobakan untuk mendapatkan gambaran secara empirik tentang kelayakan instrumen tersebut dipergunakan sebagai instrumen penelitian. Hasil uji coba dianalisis lebih lanjut untuk mendapatkan validitas, tingkat kesukaran, daya beda dan reliabilitas instrumen. Untuk mendeskripsikan data yang diperoleh digunakan teknik analisis statistik deskriptif yang meliputi, mean, median, modus, standar deviasi, dan varians. Sebelum dilakukan pengujian untuk mendapatkan

kesimpulan, terlebih dahulu dilakukan uji coba normalitas menggunakan uji Chi-Kuadrat $\left(x^{2}\right)$ pada taraf signifikansi $5 \%$ dan derajat kebebasan $\mathrm{db}=(\mathrm{k}-1)$. Dilanjutkan dengan dilakukannya uji homogenitas varians kelompok menggunakan uji $\mathrm{F}$ pada taraf signifikan 5\% dengan derajat kebebasan untuk pembilang $\mathrm{n}_{1}-1$ dan derajat kebebasan untuk penyebut $\mathrm{n}_{2}-1$. Setelah data diketahui normal dan variannya homogen maka selanjutnya dilakukan uji hipotesis menggunakan uji-t sampel independent (tidak berkolerasi). Dalam penelitian ini rumus t-test yang digunakan untuk menguji hipotesis adalah polled varians.

\section{Hasil dan Pembahasan}

Data keaktifan belajar siswa kelompok eksperimen diperoleh melalui observasi terhadap 31 orang siswa. Hasil observasi menunjukan bahwa skor tertinggi adalah 23 dan skor terendah adalah 12. Dari skor yang diperoleh dapat dideskripsikan, yaitu mean $(\mathrm{M})=17,85$, median $(\mathrm{Md})=18,21$, modus $(\mathrm{Mo})=$ 19,94 , varians $\left(s^{2}\right)=9,80$, dan standar deviasi $(s)=3,13$. Data keaktifan belajar kelompok eksperimen, dapat disajikan ke dalam bentuk kurva polygon seperti pada Gambar 1. 


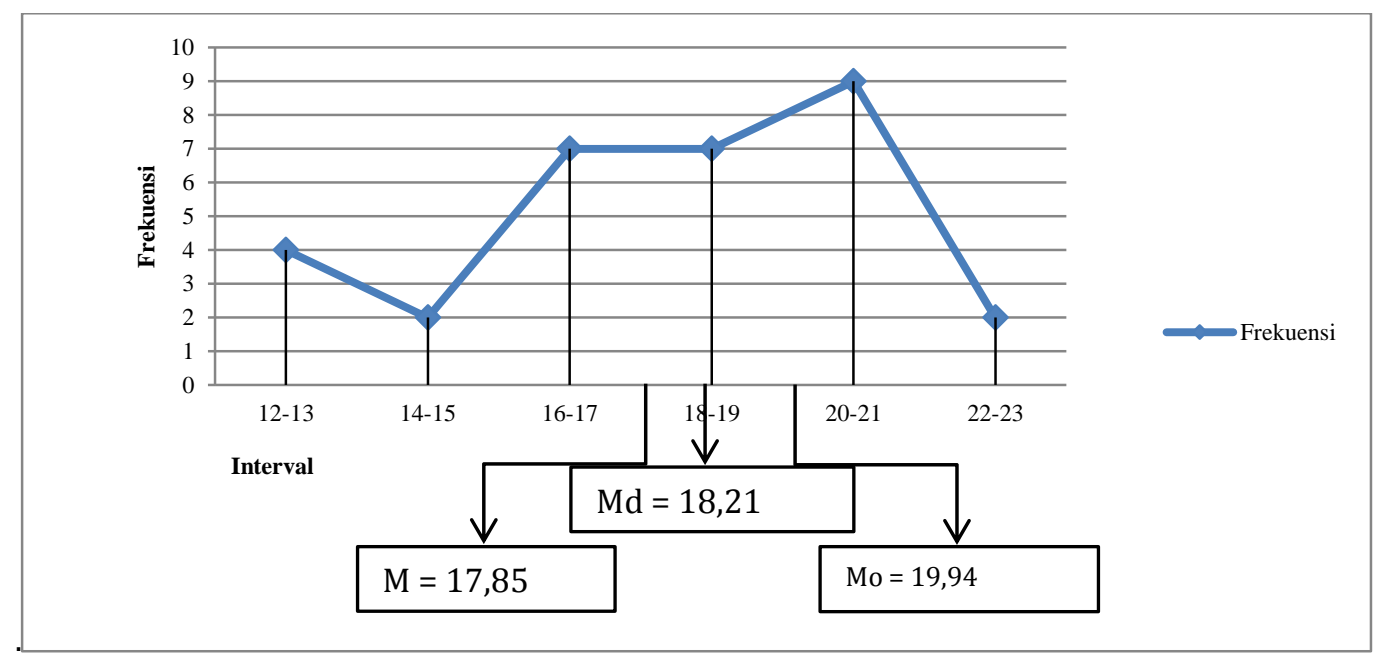

Gambar 1. Kurva Poligon Data Hasil Keaktifan Belajar Kelompok Eksperimen

Berdasarkan kurva poligon di atas, dapat diketahui modus lebih besar dari median dan median lebih besar dari mean (Mo > Md > M), sehingga kurva yang tebentuk adalah kurva juling negatif. Artinya, skor yang diperoleh adalah cenderung tinggi. Data keaktifan belajar siswa kelompok kontrol diperoleh melalui observasi terhadap 30 orang siswa. Hasil observasi menunjukan bahwa skor tertinggi adalah 15 dan skor terendah adalah 5. Dari skor yang diperoleh dapat dideskripsikan, yaitu mean $(\mathrm{M})=8,97$, median $(\mathrm{Md})=7,7$, modus $(\mathrm{Mo})=7,5$, varians $\left(s^{2}\right)=7,98$, dan standar deviasi $(\mathrm{s})=2,83$. Data keaktifan belajar kelompok kontrol, dapat disajikan ke dalam bentuk kurva polygon seperti pada Gambar 2 .

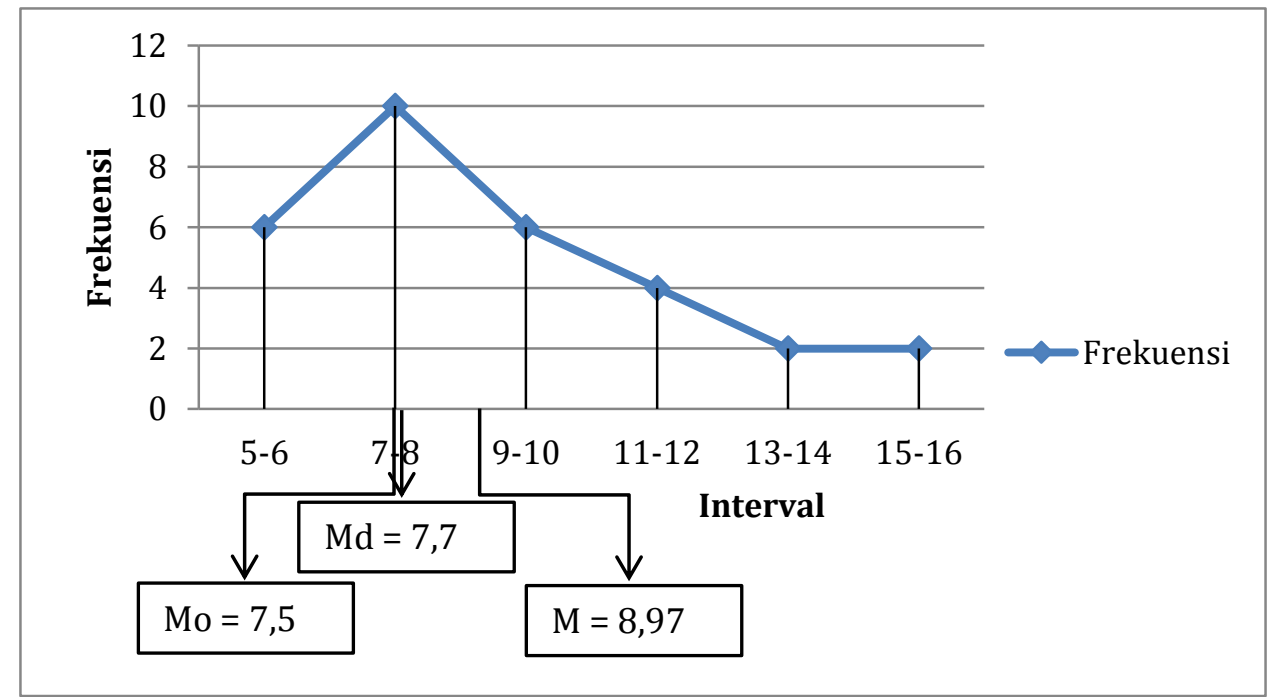

Gambar 2. Kurva Poligon Data Hasil Keaktifan Belajar Kelompok Kontrol

Berdasarkan kurva poligon di atas, dapat diketahui modus lebih kecil dari median dan median lebih kecil dari mean (Mo $<\mathrm{Md}<\mathrm{M}$ ), sehingga kurva yang terbentuk di atas adalah kurva juling positif. Artinya, skor yang diperoleh adalah cenderung rendah. Data hasil belajar IPA kelompok eksperimen diperoleh melalui post test terhadap 31 orang siswa. Hasil observasi menunjukan bahwa skor tertinggi adalah 25 dan skor terendah adalah 9. Dari skor yang diperoleh dapat dideskripsikan, yaitu mean $(\mathrm{M})=19,48$, median $(\mathrm{Md})=20,25$, modus $(\mathrm{Mo})=21,83$, varians $\left(s^{2}\right)=15,19$, dan standar deviasi $(\mathrm{s})=3,89$. Data hasil belajar IPA kelompok eksperimen, dapat disajikan ke dalam bentuk kurva polygon seperti pada gambar 3 . 


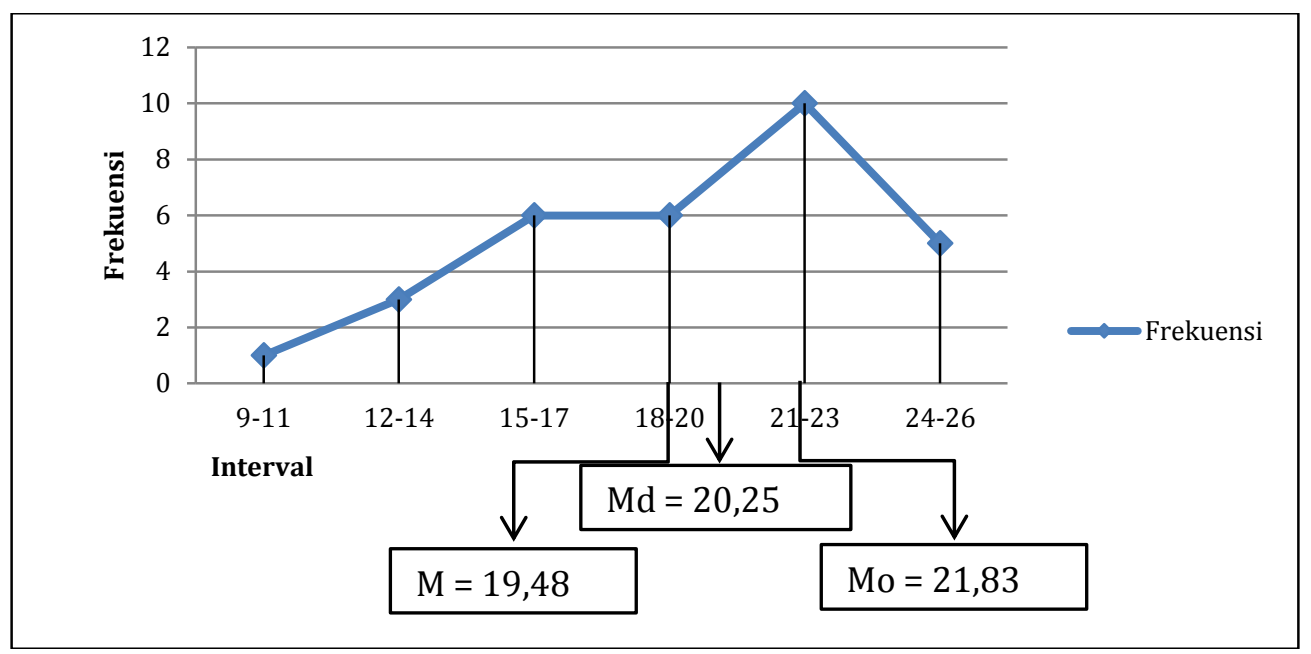

Gambar 3. Kurva Poligon Data Hasil Belajar IPA Kelompok Eksperimen

Berdasarkan kurva poligon di atas, dapat diketahui modus lebih besar dari median dan median lebih besar dari mean (Mo > Md > M), sehingga kurva yang tebentuk adalah kurva juling negatif. Artinya, skor yang diperoleh adalah cenderung tinggi. Data hasil belajar IPA kelompok kontrol diperoleh melalui post test terhadap 30 orang siswa. Hasil observasi menunjukan bahwa skor tertinggi adalah 23 dan skor terendah adalah 6. Dari skor yang diperoleh dapat dideskripsikan, yaitu mean $(\mathrm{M})=12,7$, median $(\mathrm{Md})=$ 11,5, modus $(\mathrm{Mo})=9,1$, varians $\left(s^{2}\right)=26,97$, dan standar deviasi $(\mathrm{s})=5,19$. Data hasil belajar IPA kelompok kontrol, dapat disajikan ke dalam bentuk kurva polygon seperti pada gambar 4 .

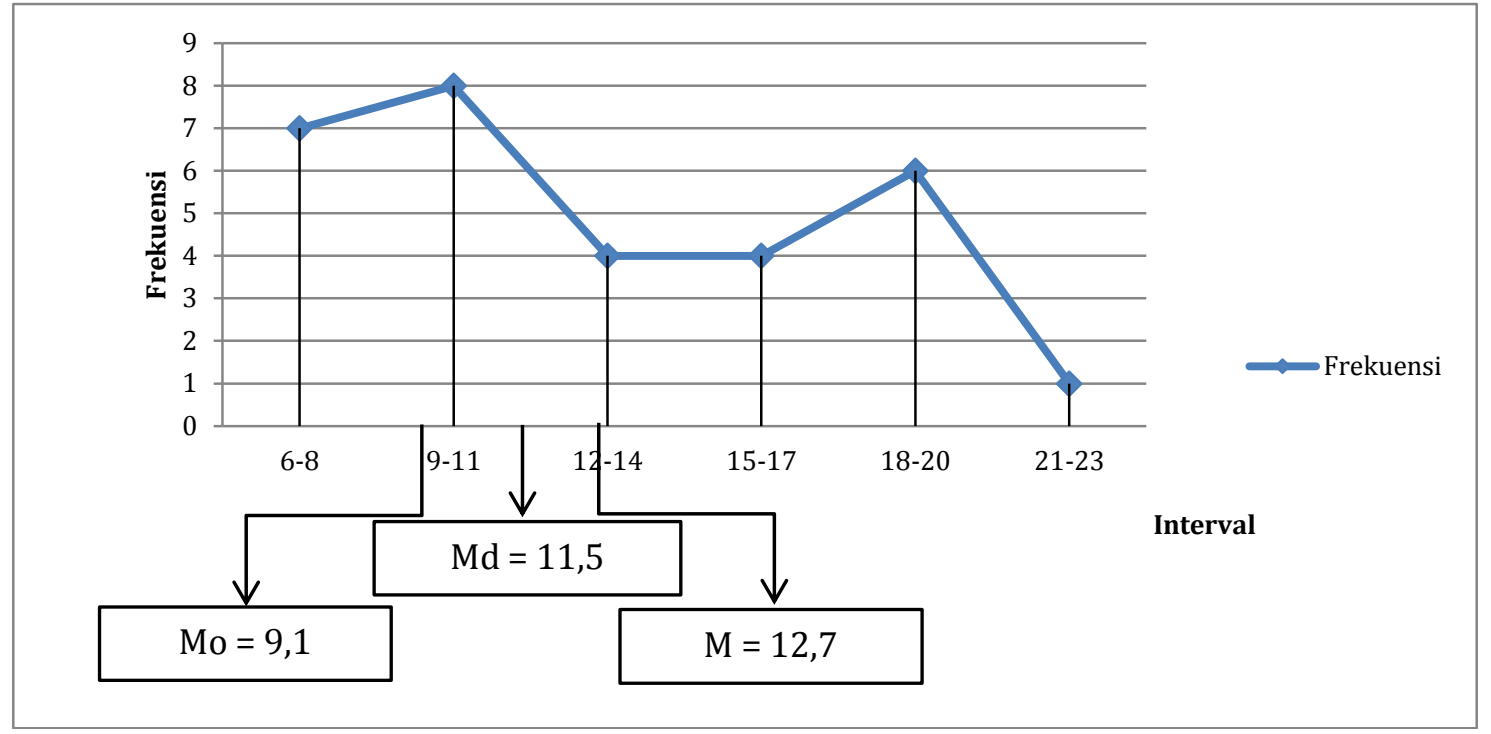

Gambar 4. Kurva Poligon Data Hasil Belajar IPA Kelompok Kontrol

Berdasarkan kurva poligon di atas, dapat diketahui modus lebih kecil dari median dan median lebih kecil dari mean $(\mathrm{Mo}<\mathrm{Md}<\mathrm{M})$, sehingga kurva yang terbentuk di atas adalah kurva juling positif. Artinya, skor yang diperoleh adalah cenderung rendah. Selanjutnya sebelum melakukan uji hipotesis, dilakukan uji normalitas sebaran data dan homogenitas kelompok varians. Berdasarkan analisis data yang dilakukan, data keaktifan belajar siswa dan hasil belajar IPA berdistribusi normal dan homogen sehingga bisa dilanjutkan pada pengujian hipotesis menggunakan uji-t sampel independent (tidak berkolerasi) dengan rumus polled varians. Kriterianya Kriteria tolak $H_{0}$ jika $t_{h i t}>t_{\text {tab }}$ dan terima $H_{0}$ jika $t_{h i t}<t_{\text {tab }}$. 
Rangkuman hasil perhitungan uji-t keaktifan belajar dapat dilihat pada Tabel 5.

Tabel 5. Rangkuman Hasil Perhitungan Uji-t Keaktifan Belajar Siswa

\begin{tabular}{lllllllll}
\hline Kelompok Data Keaktifan Belajar & Varians & $\mathrm{N}$ & $\mathrm{Db}$ & $\mathrm{t}_{\text {hitung }}$ & $\mathrm{t}_{\text {tabel }}$ & \multicolumn{2}{l}{ Kesimpulan } & \\
Kelompok Eksperimen & 9,81 & 31 & 59 & 11,64 & 2,0435 & $\mathrm{t}_{\text {hitung }}>\mathrm{t}_{\text {tabel }}$ & $\mathrm{H}_{0}$ \\
Kelompok Kontrol & 7,98 & 30 & & & & ditolak & & \\
\hline
\end{tabular}

Berdasarkan tabel 5, diperoleh $t_{\text {hit }}$ lebih besar dari $t_{t a b}\left(t_{h i t}>t_{t a b}\right)$, sehingga $\mathrm{H}^{0}$ ditolak dan $\mathrm{H}^{1}$ diterima. Dengan demikian, terdapat perbedaan yang signifikan keaktifan belajar antara kelompok siswa yang dibelajarkan dengan pembelajaran Quantum berbantuan permainan dan kelompok siswa yang dibelajarkan tidak dengan pembelajaran Quantum berbantuan permainan pada siswa kelas V SD di Gugus II Santalia Kecamatan Kubutambahan Tahun Pelajaran 2016/2017. Berikutnya, rangkuman hasil perhitungan uji-t hasil belajar IPA dapat dilihat pada Tabel 6.

Tabel 6. Rangkuman Hasil Perhitungan Uji-t Hasil Belajar IPA

\begin{tabular}{llccccc}
\hline Kelompok Data Hasil Belajar & Varians & $\mathrm{N}$ & $\mathrm{Db}$ & $\mathrm{t}_{\text {hitung }}$ & $\mathrm{t}_{\text {tabel }}$ & Kesimpulan \\
\hline Kelompok Eksperimen & 15,19 & 31 & & & & \\
Kelompok Kontrol & 26,97 & 30 & & 6,232 & $2,0435 \quad \begin{array}{l}\text { thitung }>t_{\text {tabel }} \mathrm{H}_{0} \\
\text { ditolak }\end{array}$ \\
\hline
\end{tabular}

Berdasarkan tabel 4.10, diperoleh ${ }^{t_{\text {hit }}}$ lebih besar dari $t_{t a b}\left(t_{\text {hit }}>t_{t a b}\right)$, sehingga $\mathrm{H}^{0}$ ditolak dan

$\mathrm{H}^{1}$ diterima. Dengan demikian, terdapat perbedaan yang signifikan hasil belajar IPA antara kelompok siswa yang dibelajarkan dengan pembelajaran Quantum berbantuan permainan dan kelompok siswa yang dibelajarkan tidak dengan pembelajaran Quantum berbantuan permainan pada siswa kelas V SD di Gugus II Santalia Kecamatan Kubutambahan Tahun Pelajaran 2016/2017.

Berdasarkan penelitian yang dilakukan, terdapat perbedaan rata-rata skor keaktifan belajar siswa dan hasil belajar IPA pada kelompok eksperimen dan kelompok kontrol. Secara deskriptif, keaktifan belajar dan hasil belajar IPA kelompok eksperimen lebih tinggi dibandingkan dengan kelompok kontrol. Perbedaan tersebut menunjukan bahwa pembelajaran Quantum berbantuan permainan berpengaruh terhadap keaktifan belajar siswa dan hasil belajar IPA siswa kelas V.

Temuan penelitian yang menunjukan bahwa pembelajaran Quantum berbantuan permainan berpengaruh terhadap keaktifan dan hasil belajar IPA siswa disebabkan oleh beberapa faktor. Pertama, pembelajaran Quantum memberikan kesempatan kepada siswa untuk berinteraksi langsung dalam lingkungan belajar, sehingga siswa akan lebih memahami pembelajaran yang dilaksanakan. Interaksi yang dilakukan oleh siswa berkaitan dengan kegiatan siswa berdiskusi untuk memecahkan suatu permasalahan. Memecahkan suatu permasalahan memberikan kesempatan pada siswa untuk mengeluarkan kemampuannya dan membantu siswa terlatih berpartisipasi dalam kelompoknya secara demokratis. Kegiatan diskusi akan meningkatkan keaktifan siswa. Selain hal tersebut, kegiatan diskusi membantu siswa agar dapat belajar secara bermakna. Kebermaknaan yang dialami siswa akan sangat berpengaruh terhadap pemahaman siswa pada pembelajaran IPA. Dengan demikian, dapat dikatakan bahwa pembelajaran Quantum memberikan kesempatan pada siswa untuk lebih aktif berinteraksi terhadap lingkungan belajar melalui kegiatan diskusi, sehingga siswa dapat belajar bermakna dan berpengaruh terhadap keaktifan serta hasil belajar siswa. Pendapat tersebut sesuai dengan pendapat Deporter, dkk (2010) yang menyatakan, pembelajaran Quantum dapat menciptakan lingkungan belajar yang efektif, melalui interaksi antara siswa dan lingkungan belajarnya yang terjadi di dalam kelas. Berikutnya, Harahap (dalam Vitasari, 2016) menyatakan, kegiatan siswa dalam berdiskusi untuk menyelesaikan masalah, mengemukakan pendapat atau bertanya, dan mempresentasikan hasil diskusi merupakan indikator keaktifan belajar. Selain hal tersebut, siswa mampu memperoleh pemahaman berdasarkan apa yang dilihat, didengar, dirasakan, dan dialami sendiri oleh siswa (Suastra, 2009). Pendapat tersebut, didukung oleh penelitian yang dilakukan oleh Asrori (2013) yang menyatakan bahwa, Quantum Learning dapat menciptakan lingkungan belajar yang aktif dan komunikatif sehingga dapat 
mencapai tujuan pembelajaran secara maksimal. Selain hal tersebut, interaksi antara siswa, guru dan pihak sekolah memberikan pengaruh yang lebih baik terhadap aktivitas dan hasil belajar siswa. Syukur (2014) juga menyatakan bahwa, pembelajaran Quantum dapat melatih siswa untuk bekerja sama dalam kelompok dan siswa diberikan kesempatan untuk menjalin interaksi keakraban dalam pembelajaran.

Kedua, permainan yang diterapkan menjadikan pembelajaran semakin menyenangkan. Keaktifan belajar siswa menjadi semakin meningkat. Hal tersebut terlihat ketika masing-masing kelompok bersemangat menyelesaikan permainan dan mengatur strategi agar secepat mungkin menyelesaikan permainan. Selain hal tersebut, keaktifan siswa terlihat dari antusias siswa ketika diberikan kesempatan untuk menjawab pertanyaan. Banyak siswa yang mengangkat tangan untuk menjawab pertanyaanpertanyaan yang diajukan. Dengan demikian, dapat dikatakan bahwa, permainan dapat menciptakan pembelajaran yang menyenangkan dan mampu meningkatkan keaktifan siswa dalam pembelajaran. Jika siswa sudah aktif belajar, maka hasil belajarnya juga menjadi lebih baik. Pendapat tersebut sesuai dengan pendapat Hurlock (dalam Suyadi, 2010) yang menyatakan, bermain atau permainan merupakan aktivitas yang dilakukan untuk memperoleh kesenangan. Berikutnya, pendapat tersebut sesuai dengan hasil penelitian yang dilakukan oleh Darma (2014) yang menyatakan, pelaksanaan permainan dalam pembelajaran memberikan kesempatan kepada siswa untuk terlibat aktif dalam proses pembelajaran, sehingga keaktifan siswa menjadi lebih meningkat. Selain hal tersebut, Ambarjaya (2012) menyatakan, keaktifan siswa dalam belajar memberikan kesempatan yang lebih luas untuk memperoleh dan memahami pengetahuan baru, sehingga berpengaruh terhadap hasil belajar siswa menjadi lebih baik.

Ketiga, penggunaan media pembelajaran video membantu siswa lebih memahami materi yang dipelajari. Penggunaan media video dapat menghidupkan suasana pembelajaran di kelas, sehingga siswa tidak bosan mengikuti pembelajaran. Selain hal tersebut, dengan media video siswa menjadi lebih termotivasi dalam belajar, sehingga siswa lebih mudah memahami materi yang dipelajari. Dengan demikian, dapat dikatakan bahwa media pembelajaran dapat meningkatkan keaktifan siswa dalam pembelajaran dan membantu siswa dalam menyerap materi pelajaran dengan lebih baik. Pendapat tersebut sesuai dengan pendapat Yamin (2017) yang menyatakan, media dapat meningkatkan keingintahuan siswa, merangsang siswa untuk aktif belajar, dan dapat menghidupkan suasana belajar. Berikutnya, pendapat tersebut juga sesuai dengan hasi penelitian Alvionita (2013) yang menyatakan, media video dapat merangsang siswa untuk melakukan aktivitas yang relevan dalam pembelajaran. Hal ini terbukti dari aktivitas siswa dalam bertanya, menjawab petanyaan, mengajukan pendapat/ide dalam diskusi, dan mempresentasikan hasil diskusi yang dilakukan siswa pada kelas berkriteria tinggi. Peningkatan aktivitas tersebut dapat mempengaruhi peningkatan penguasaan materi siswa. Selanjutnya, hasil penelitian yang dilakukan oleh Iwantara (2014) juga menyatakan bahwa, media video dapat memvisualisasikan konsep yang abstrak menjadi lebih nyata, sehingga membuat siswa lebih termotivasi untuk belajar dan membantu pembentukan pemahaman konsep siswa menjadi lebih baik.

Keempat, penghargaan memberikan kesan pada siswa bahwa usaha yang mereka laksanakan selama pembelajaran patut dihargai dan dirayakan. Penghargaan yang diberikan meliputi pemberian tepuk tangan, pujian, pemberian tanda penghargaan, dan bernyanyi bersama. Penghargaan tersebut mengakibatkan siswa semakin termotivasi dalam belajar, sehingga siswa semakin aktif dalam belajar dan berdampak pula pada hasil belajar siswa. Dengan demikian, dapat dikatakan bahwa penghargaan dapat meningkatkan keaktifan belajar siswa, yang berpengaruh pula terhadap keberhasilan hasil belajar siswa. Pendapat ini sesuai dengan pendapat Deporter, dkk (2010) yang menyatakan, sesuatu yang layak dipelajari maka layak pula untuk dirayakan. Berikutnya, menurut Arifin (dalam Lisyaningrum, 2015), penghargaan, ganjaran, hadiah, reward merupakan suatu rangsangan yang diberikan kepada siswa untuk memperkuat suatu respon tertentu. Pendapat tersebut, didukung oleh penelitian yang dilakukan oleh Natalia (2014) yang menyatakan bahwa, pemberian penghargaan di kelas menjadikan siswa lebih bersemangat untuk berhasil dalam pembelajaran dan menjadikan siswa lebih fokus ketika guru menjelaskan. Dengan demikian, motivasi dan hasil belajar siswa menjadi meningkat. Hasil penelitian Lisyaningrum (2015) juga menyatakan, pemberian penghargaan menjadikan siswa lebih antusias dalam mengikuti proses pembelajaran di kelas dan menjadikan siswa lebih percaya diri dalam mengemukakan pendapat maupun mengajukan pertanyaan. Dengan demikian, motivasi dan hasil belajar kognitif siswa menjadi semakin meningkat.

Selanjutnya, berkenaan dengan rata-rata skor keaktifan belajar pada kelompok siswa yang dibelajarkan tidak dengan model pembelajaran Quantum berada pada kategori cukup dipengaruhi oleh perubahan proses pembelajaran yang dilakukan guru. Guru menggunakan media berupa video dan adanya penghargaan yang diberikan selama pembelajaran. Suasana di kelas menjadi lebih hidup, sehingga siswa tidak bosan dalam belajar. Selain hal tersebut, siswa lebih termotivasi untuk mengangkat tangan ketika guru memberikan pertanyaan yang berkaitan dengan materi yang dipelajari, sehingga berpengaruh terhadap keaktifan mereka. 
Berdasarkan uraian di atas, terlihat jelas bahwa pembelajaran Quantum berbantuan permainan dapat meningkatkan keaktifan belajar siswa yang berdampak pula terhadap hasil belajar siswa. Tidak hanya itu, pembelajaran Quantum juga dapat meningkatkan motivasi, aktivitas, dan pemahaman konsep siswa. Keberhasilan penelitian-penelitian tersebut mendukung keberhasilan penelitian tentang pengaruh pembelajaran Quantum berbantuan permainan dalam pembelajaran terhadap keaktifan dan hasil belajar kognitif IPA siswa kelas V di gugus II Santalia Kecamatan Kubutambahan tahun pelajaran 2016/2017. Berdasarkan hal tersebut, pembelajaran ini dapat diterapkan sebagai variasi dalam kegiatan pembelajaran, sehingga siswa tidak mudah jenuh, pembelajaran menjadi lebih menyenangkan, siswa menjadi lebih aktif dalam belajar, dan pada akhirnya hasil belajar dapat dioptimalkan.

\section{Kesimpulan}

Berdasarkan hasil dan pembahasan, dapat disimpulkan sebagai berikut. (1) terdapat perbedaan yang signifikan keaktifan belajar antara kelompok yang dibelajarkan dengan pembelajaran Quantum berbantuan permainan dan kelompok siswa yang dibelajarkan tidak dengan pembelajaran Quantum berbantuan permainan pada siswa kelas V SD di Gugus II Santalia Kecamatan Kubutambahan Tahun Pelajaran 2016/2017. Hasil pengujian menunjukkan bahwa thitung $(11,608)$ lebih besar dari pada tabel $(2,000)$ pada taraf signifikansi $5 \%$ dengan $\mathrm{db}=59$. (2) terdapat perbedaan yang signifikan hasil belajar IPA antara kelompok siswa yang dibelajarkan dengan pembelajaran Quantum berbantuan permainan dan kelompok siswa yang dibelajarkan tidak dengan pembelajaran Quantum berbantuan permainan pada siswa kelas V SD di Gugus II Santalia Kecamatan Kubutambahan Tahun Pelajaran 2016/2017. Hasil pengujian menunjukkan bahwa thitung $(6,232)$ lebih besar dari pada tabel $(2,000)$ pada taraf signifikansi $5 \%$ dengan $\mathrm{db}=59$.

Saran yang dapat disampaikan berdasarkan penelitian yang telah dilakukan adalah sebagai berikut. (1) siswa hendaknya lebih aktif mencari sumber belajar lain sebagai tambahan referensi dalam pembelajaran. (2) guru di sekolah dasar hendaknya menggunakan lebih banyak pembelajaran yang inovatif dalam pembelajaran agar pembelajaran menjadi lebih bervariasi. (3) kepala sekolah hendaknya mengikutkan guru-guru dalam pelatihan mengenai pembelajaran inovatif dan mengupayakan untuk menambah media pembelajaran yang relevan dengan pembelajaran di sekolah. (4) permainan-permainan yang dapat digunakan dalam pembelajaran IPA belum banyak termuat dalam pustaka. Untuk itu, peneliti lain hendaknya dapat mengembangkan pustaka yang memuat permainan dalam pembelajaran IPA sebagai penelitian lanjutan.

\section{Daftar Rujukan}

Alvionita, Vivi. 2013. "Pengaruh Penerapan Media Video Terhadap Aktivitas dan Penguasaan Materi Pokok Sistem Pernapasan". Jurnal Bioterdidik, Volume 1, No 7 (hal 8). Diakses pada tanggal 20 Juni 2017.

Ambarjaya, Beni S. 2012. Psikologi Pendidikan \& Pengajaran Teori \& Praktik. Yogyakarta: CAPS.

Asrori, Sofiyah. 2014. "Penerapan Quantum Learning untuk Meningkatkan Aktivitas Belajar Siswa Pada Mata Pelajaran PKn di Kelas V SD Negeri Kembangjitengan 2 Kabupaten Sleman". Kalam Cendekia PGSD Kebumen, Volume 3, No 1 (hal 6). Diakses pada tanggal 20 Juni 2017.

Darma, Putri. 2014. "Pengaruh Pembelajaran Biologi Melalui Metode Permainan dengan Media Kartu Kwartet Terhadap Keaktifan dan Hasil Belajar Siswa Kelas VII Smp Negeri 13 Kabupaten Jember Tahun Ajaran 2012/2013". Pancaran Pendidikan, Volume 3, No 1 (hal 3-7). Diakses pada tanggal 20 Juni 2017.

Deporter, dkk. 2010. Quantum Teaching Mempraktikkan Quantum Learning di Ruang-ruang Kelas. Bandung: Kaifa.

Iwantara, I Wayan. 2014. "Pengaruh Penggunaan Media Video Youtube dalam Pembelajaran IPA Terhadap Motivasi Belajar dan Pemahaman Konsep Siswa". Jurnal Pendidikan IPA, Volume 4, No 1 (hal 9). Diakses pada tanggal 20 Juni 2017.

Lisyaningrum, Nenie. 2015. "Upaya Meningkatkan Kualitas Pembelajaran Akuntansi Melalui Penerapan Strategi Pembelajaran Aktif Tipe Index Card Match dengan Teknik Penghargaan (Reward)". Tata Arta, Volume 1, No 2 (hal 10). Diakses pada tanggal 20 Juni 2017.

Natalia. 2014. "Pengaruh Pemberian Penghargaan Oleh Guru Ekonomi Terhadap Motivasi Belajar Siswa Kelas X MAN 2 Pontianak". Jurnal Pendidikan dan Pembelajaran, Volume 3, No 6 (hal 9). Diakses pada tanggal 20 Juni 2017.

Samatowa, Usman. 2016. Pembelajaran IPA di Sekolah Dasar. Jakarta: PT Indeks. 
Suastra, I Wayan. 2009. Pembelajaran Sains Terkini Mendekatkan Siswa dengan Lingkungan Alamiah dan Sosial Budaya. Singaraja: Universitas Pendidikan Ganesha.

Sudono, Anggani. 2000. Sumber Belajar dan Alat Permainan (untuk Pendidikan Anak USia Dini). Jakarta: PT Gramedia.

Susanto, Ahmad. 2013. Teori Belajar dan Pembelajaran Di Sekolah Dasar. Jakarta: Prenadamedia Group.

Suwatra, dkk. 2015. Belajar dan Pembelajaran Sekolah Dasar. Singaraja: UNDIKSHA.

Suyadi. 2010. Psikologi Belajar Pendidikan Anak Usia Dini. Yogyakarta: PT Pustaka Insan Madani.

Syukur, Muhammad dkk. 2014. "Pengaruh Model Pembelajaran Quantum Teaching Terhadap Hasil Belajar Siswa SD". Program Studi Pendidikan Dasar FKIP Universitas Tanjungpura (hal 10). Diakses pada tanggal 25 Januari 2017.

Vitasari, Rizka. 2016. "Peningkatan Keaktifan dan Hasil Belajar Matematika Melalui Model Problem Based Learning Siswa Kelas V SD Negeri 5 Kutosari”. Kalam Cendekia PGSD Kebumen, Volume 5, No 3 (hal 2). Diakses pada tanggal 18 Juni 2017.

Yamin, Martinis. 2007. Desain Pembelajaran Berbasis Tingkat Satuan Pendidikan. Jakarta: Gaung Persada Press. 